\title{
A solid-phase extraction method using Transcarpathian clinoptilolite for preconcentration of trace amounts of terbium in water samples
}

\author{
Volodymyr O. Vasylechko ${ }^{1,2^{*}}$, Galyna V. Gryshchouk', Victor P. Zakordonskiy ${ }^{1}$, Olga Vyviurska ${ }^{1}$ and Andriy V. Pashuk ${ }^{3}$
}

\begin{abstract}
Background: In spite of the fact that terbium is one of the rarest elements in the Earth's crust, it is frequently used for the production of high technological materials. At the result, an effective combination of sample preparation procedure and detection method for terbium ions in different matrices is highly required. The solid-phase extraction procedure with natural Transcarpathian clinoptilolite thermally activated at $350^{\circ} \mathrm{C}$ was used to preconcentrate trace amounts of terbium ions in aqueous solutions for a final spectrophotometric determination with arsenazo III.

Results: Thermogravimetric investigations confirmed the existence of relations between changes that appeared during dehydratation of calcined zeolite and its sorption affinity. Since the maximum of sorption capacity towards terbium was observed at $\mathrm{pH} 8.25$, a borate buffer medium $\left(2.5 \cdot 10^{-4} \mathrm{M}\right)$ was used to maintain ionic force and solution acidity. Terbium was quantitatively removed from the solid-phase extraction column with a $1.0 \mathrm{M}$ solution of sodium chloride $\left(\mathrm{pH}\right.$ 2.5). The linearity of the proposed method was evaluated in the range of $2.5-200 \mathrm{ng} \cdot \mathrm{mL}^{-1}$ with detection limit $0.75 \mathrm{ng} \cdot \mathrm{mL}^{-1}$.

Conclusions: Due to acceptable recoveries (93.3-102.0 \%) and RSD values (6-7.1) from spiked tap water, the developed method can be successfully applied for the determination of trace amounts of terbium ions in the presence of major components of water.
\end{abstract}

Keywords: Preconcentration, Terbium, Solid-phase extraction, Clinoptilolite

\section{Background}

Terbium belongs to the rarest elements, participating with $1.1 \cdot 10^{-4} \%$ in the composition of the Earth's crust [1], and this is only $1.0 \%$ among all lanthanides including yttrium. At the same time terbium compounds have been widely applied for luminophores, magnetic and laser materials. Furthermore, this lanthanide was detected in sea and mineral waters [2] as well as in some wines at the microlevel. For example, the content of terbium and other rare earth elements was used for authentication of Hungarian wines [3]. In general, the determination of microelements from real samples and wastewaters requires a proper sample preparation procedure, including such steps as preconcentration,

\footnotetext{
* Correspondence: vasylechko@ukr.net

${ }^{1}$ Faculty of Chemistry, Ivan Franko National University of Lviv, 6 Kyryla and

Mefodiya St., 79005 Lviv, Ukraine

${ }^{2}$ Department of Chemistry and Physics, Lviv Academy of Commerce, 9

Samchuka St., 79011 Lviv, Ukraine

Full list of author information is available at the end of the article
}

separation and isolation from natural objects and process liquors. In this case, ion exchange and extraction chromatography were found to be effective and fast for the separation of trace amounts of rare earth elements [4, 5]. At the same time, the solid-phase extraction (SPE) has also become quite popular sample preparation procedure for trace analysis [5-9], allows to reduce solvent consumption due to a simplified procedure of the solvent removal. Furthermore, SPE could be easily combined with the selective and high sensitive methods of the analysis, e.g. atomic absorption spectroscopy $[9,10]$ and inductively coupled plasma spectroscopy [5-7]. A variety of sorbents such as modified high dispersed silica $[5,11,12]$, activated carbon $[5,13,14]$, polyurethane foams $[15,16]$, polymeric resins $[9,17]$, carbosilicon [18], synthetic zeolites [19] are commonly used for solid phase extraction. In recent years, the popularity of natural zeolites has increased for SPE applications $[6,10,20-29]$, because of a number of advantages over 
the other sorbents. For example, these natural aluminosilicate minerals contain pores and cavities with strictly defined size and shape, and it provides very effective concentration and separation of organic and inorganic compounds. In addition, zeolites have mechanical strength, good stability in aggressive medium and under thermal treatment, ability to sorb the trace amounts of analytes, high sorption capacity and selectivity, possibility of easy modification and regeneration of the sorbent, low cost and accessibility. The sorption properties of Transcarpathian clinoptilolite towards terbium ions were described in our previous work [30]. The aim of this study is to complete these investigations and to develop a simple sample preparation procedure for the spectrophotometric detection of trace amounts of terbium ions in aqueous solutions.

\section{Experimental}

\section{Reagents and apparatus}

All used reagents were of analytical grade. Standard aqueous solutions of terbium(III) nitrate $\left(1.0 \mathrm{mg} \cdot \mathrm{mL}^{-1}\right)$ were prepared by dissolution of metallic terbium ( $99.9 \%$ purity) in nitric acid (1:1). The following solutions were also used for the experiments: a $0.05 \%$ solution of sulfarsazene in a $0.05 \mathrm{M}$ borax solution, a $0.05 \%$ aqueous solution of arsenazo III, a $1 \%$ ascorbic acid solution, a formic buffer solution $(60 \mathrm{~mL}$ of formic acid and $28 \mathrm{~g}$ of $\mathrm{NaOH}$ are dissolved in $1.0 \mathrm{~L}$ of water), a $1 \mathrm{M}$ sodium chloride solution, a $5 \%$ sulphosalicylic acid solution, a $0.2 \mathrm{M}$ EDTA solution, a $0.1 \mathrm{M}$ aqueous solutions of $\mathrm{NaOH}$ and $\mathrm{Na}_{2} \mathrm{~B}_{4} \mathrm{O}_{7}$, and a borate buffer solution with pH $8.25(595 \mathrm{~mL}$ of 0.05 $\mathrm{M} \mathrm{Na}_{2} \mathrm{~B}_{4} \mathrm{O}_{7}$ diluted to $1.0 \mathrm{~L}$ with $0.1 \mathrm{M} \mathrm{HCl}$ ). Clinoptilolite samples with $85-90 \%$ of the main component content were taken from the deposit near the village Sokirnytsia in the Ukrainian Transcarpathian region. The specific surface area measured with water sorption was found to be $59 \mathrm{~m}^{2} \cdot \mathrm{g}^{-1}$ [31]. The chemical composition of Transcarpathian clinoptilolite is (in \%): $\mathrm{SiO}_{2}, 67.29 ; \mathrm{TiO}_{2}, 0.26$; $\mathrm{Al}_{2} \mathrm{O}_{3}, 12.32 ; \mathrm{Fe}_{2} \mathrm{O}_{3}, 1.26 ; \mathrm{FeO}, 0.25 ; \mathrm{MgO}, 0.99 ; \mathrm{CaO}$, 3.01; $\mathrm{Na}_{2} \mathrm{O}, 0.66 ; \mathrm{K}_{2} \mathrm{O}, 2.76 ; \mathrm{H}_{2} \mathrm{O}, 10.90$ [32]. The thermal heating of Transcarpathian clinoptilolite was carried out for $2.5 \mathrm{~h}$ in the oven. The results of the X-ray analysis of the calcined Transcarpathian clinoptilolite were described in details in our previous study [33]. Spectrophotometric determination was performed on a HACH DR/4000 V spectrophotometer. X-ray fluorescence investigations were carried out on an Expert $3 \mathrm{~L}$ multi element rapid response analyzer (INAM, Ukraine) with semiconducting PINdetector (AMPTEK, USA) on thermoelectric cooling. A low-power X-ray tube was operated at $45 \mathrm{kV}$ (current 0.1 $\mathrm{mA}$, output $4.5 \mathrm{~W}$ ). In this case, $2 \mathrm{~mL}$ of the sample was placed into the cuvette, and $\mathrm{Tb} \mathrm{L} \alpha$ line radiation was measured for 285 s. The Paulik-Paulik-Erdey Q-1500D
(MOM, Hungary) system was employed for thermogravimetric analysis.

\section{Adsorption measurements}

The sorption properties of clinoptilolite were studied under dynamic conditions using a peristaltic pump, and the procedure was described in details in our previous paper [34]. The metal solutions were passed through a sorption cartridge filled with $0.6 \mathrm{~g}$ of sorbent at a flow rate of $3 \mathrm{~mL} \cdot \mathrm{min}^{-1}$. A passing moment of terbium(III) ions (LDL, $100 \mathrm{ng} \cdot \mathrm{mL}^{-1}$ ) was detected visually and/or spectrophotometrically at $540 \mathrm{~nm}$ with sulfarsazene as a chromogenic reagent, and additionally confirmed by Xray fluorescence.

An acidified solution of sodium sulphate and mineral acids solutions were used for desorption of $\mathrm{Tb}(\mathrm{III})$ ions from clinoptilolite. In this case $15 \mathrm{~mL}$ of eluent was passed through the sorption cartridge at a flow rate of $1 \mathrm{~mL} \cdot \mathrm{min}^{-1}$. The obtained eluate was collected into a volumetric glass flask and made up to $25 \mathrm{~mL}$ using double-distilled water.Since selectivity of determination of $\mathrm{Tb}$ (III) ions with sulfarsazene was insufficient for the analysis of desorption filtrates, a content of $\mathrm{Tb}(\mathrm{III})$ ions was found spectrophotometrically with arsenazo III as a reagent $[35,36]$. Interference of $\mathrm{Fe}(\mathrm{III}), \mathrm{Al}(\mathrm{III}), \mathrm{Ca}(\mathrm{II})$ and $\mathrm{Mn}$ (II) ions was eliminated by the addition of ascorbic and sulphosalicylic acids, EDTA and Seignette salt to the system. The adsorption and desorption studies were carried out at a temperature of $20 \pm 1{ }^{\circ} \mathrm{C}$.

\section{Method of spectrophotometric determination with arsenazo III}

$5 \mathrm{~mL}$ of an $1 \%$ ascorbic acid solution, $4 \mathrm{~mL}$ of a $4 \%$ sulphosalicylic acid solution, $5 \mathrm{~mL}$ of a $0.2 \mathrm{M}$ EDTA solution, $3 \mathrm{~mL}$ of a $5 \%$ Seignette salt solution were mixed with $25 \mathrm{~mL}$ of the analysed solution ( $\mathrm{pH} \sim 1)$. After $2 \mathrm{~min}$, a mixture of $1 \mathrm{~mL}$ of a formic buffer solution (pH 3.5) and $4 \mathrm{~mL}$ of a $0.05 \%$ arsenazo III solution was diluted with double-distilled water to approximately $40 \mathrm{~mL}$ and regulated to $\mathrm{pH} 2.6 \pm 0.1$ with a $0.1 \mathrm{M} \mathrm{NaOH}$. The final volume of the solution was made up to $50 \mathrm{~mL}$ with doubledistilled water, and the absorbance was measured spectophotometrically at $650 \mathrm{~nm}$ against the blank solution which contains all the reagents except for terbium(III) ions. The quantitative determination of terbium(III) ions was carried out in the final volume of the solution (in concentration range of $0.1-2 \mu \mathrm{g} \cdot \mathrm{mL}^{-1}$ ).

\section{Thermogravimetric analysis}

The analysis was performed under air conditions with the heating rate $10{ }^{\circ} \mathrm{C} \cdot \mathrm{min}^{-1}$ from 50 to $900{ }^{\circ} \mathrm{C}$ with $\mathrm{Al}_{2} \mathrm{O}_{3}$ as a standard material. Clinoptilolite samples (grain size $0.20-0.31 \mathrm{~mm}$ ) weighting $500-510 \mathrm{mg}$ were placed in corundum crucibles. The sorbent was preliminary heated in a 
drying oven or a muffle oven during $2.5 \mathrm{~h}$ and stored in a desiccator above a saturated solution of $\mathrm{H}_{2} \mathrm{SO}_{4}$.

\section{Results and discussion}

As can be seen from the Fig. 1, the sorption capacity of Transcarpathian clinoptilolite towards terbium(III) ions considerably depends on the $\mathrm{pH}$ of analyte solution and previous thermal treatment of the used zeolite. The most effective sorption was observed in the weak alkaline solutions $(\mathrm{pH}$ 8.25), where according to our previous studies [30], terbium(III) ions exist in three cation forms of $\mathrm{Tb}^{3+}$ ( 25\%), $\mathrm{TbOH}^{2+}(\sim 50 \%)$ and $\mathrm{Tb}(\mathrm{OH})_{2}{ }^{+}(\sim 25 \%)$. In order to maintain $\mathrm{pH}$ and improve the accuracy of the investigations, a borate buffer was added to terbium solution. Consequently, it was found that the same amounts of terbium(III) ions were concentrated from the solution adjusted to $\mathrm{pH} 8.25$ with sodium hydroxide at once and from the solution which was firstly neutralized, then buffered to $\mathrm{pH}$ 8.25. Moreover, the use of the buffer solution provides a possibility to keep constant ionic strenght, and minimize the negative influence of different admixtures on the effectiveness of terbium preconcentration.

As to the thermal treatment of Transcarpathian clinoptilolite, a minimum at $250{ }^{\circ} \mathrm{C}$ and a maximum at $350{ }^{\circ} \mathrm{C}$ of sorption capacity for terbium were observed over a narrow temperature range (Fig. 1). These observations confirmed the connection between zeolite structural changes during dehydration processes and its sorption abilities [23-31, 33, 34, 37]. At the same time, only partial rehydration of zeolite could be observed in distilled water, e.g. water content of Transcarpathian clinoptilolite was reduced by $18 \mathrm{wt}$. $\%$ after thermal treatment at $500{ }^{\circ} \mathrm{C}$. As a result, the sorption effectiveness of thermally activated zeolite towards trace element ions was not further diminished in aqueous solutions.

The results of our previous investigations [30] showed that efficiency of exchangeable cations and specific surface value of clinoptilolite change after thermal treatment of the sorbent. Similarly, specific surface area and sorption capacity of thermally treated clinoptilolite samples depend on the pretreatment temperature. Conseqently, an additional thermogravimetric experiment was carried out to investigate the thermal desorption of water from the clinoptilolite surface. Figure 2 illustrates TG-and DTG-curves of natural clinoptilolite and clinoptilolite thermally activated at $500{ }^{\circ} \mathrm{C}$. It appears that TGand DTG-curves have almost identical shapes. TG-curve entirely represents physical and chemical transformations of the sample during continuous heating. The observed plateau at $600-700{ }^{\circ} \mathrm{C}$ has an $\mathrm{S}$-form which is typical for minerals. At the same time, TG-curve suggests the influence of previous thermal treatment of the sorbent on its adsorption capacity for water. These results could be confirmed by DTG-curves (Fig. 3) and data of the overall

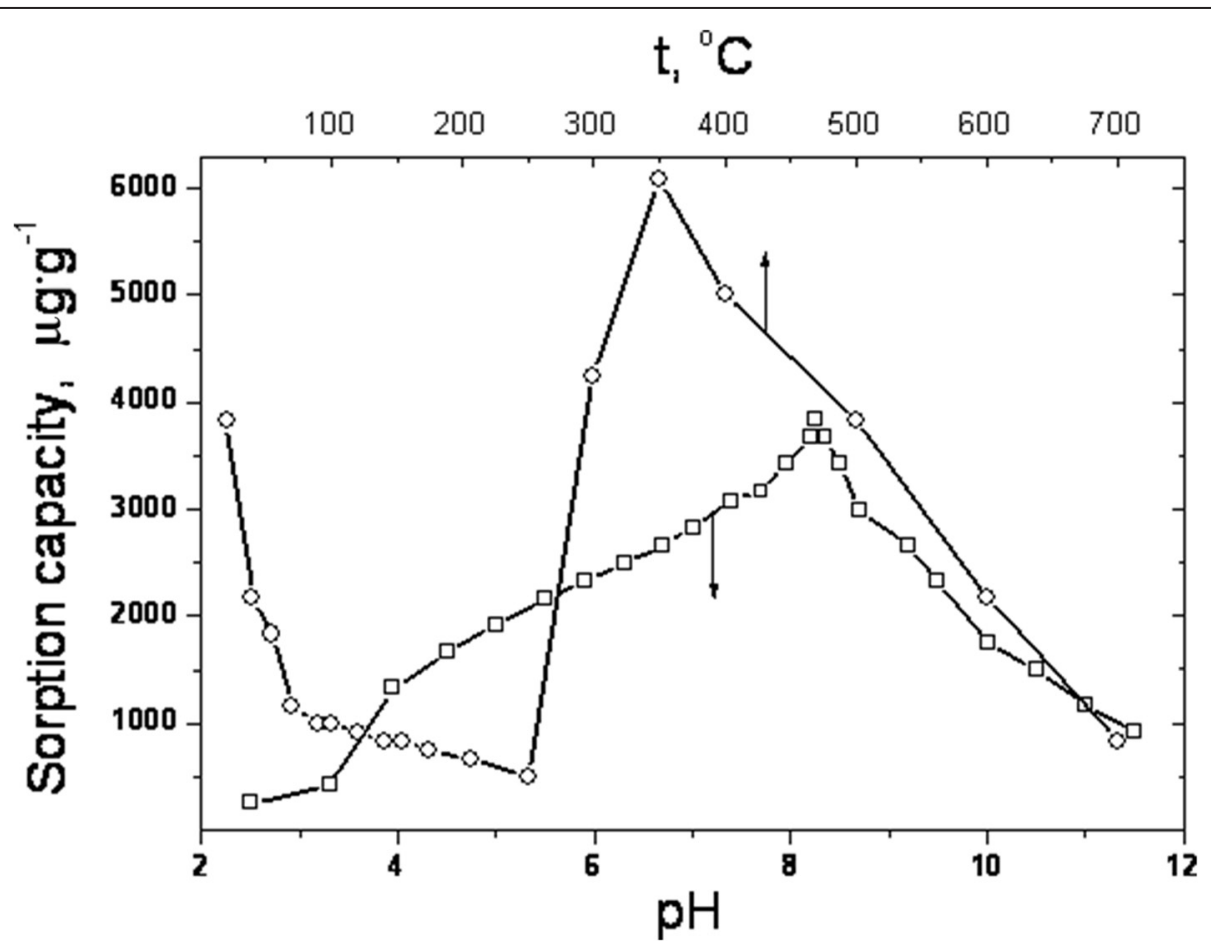

Fig. 1 Dependence of clinoptilolite sorption capacity of terbium(III) ions on a pH value of the aqueous solution and thermal treatment carried out in the range from 20 to $700{ }^{\circ} \mathrm{C}\left(\mathrm{pH}\right.$ 8.25) (concentration of $\mathrm{Tb}(\mathrm{III})-1 \mu \mathrm{gg} \cdot \mathrm{mL}^{-1} ; \mathrm{pH} 8.25$; a flow rate $-3 \mathrm{~mL} \cdot \mathrm{min}^{-1}$; time of heat treatment $-2.5 \mathrm{~h}$ ) 


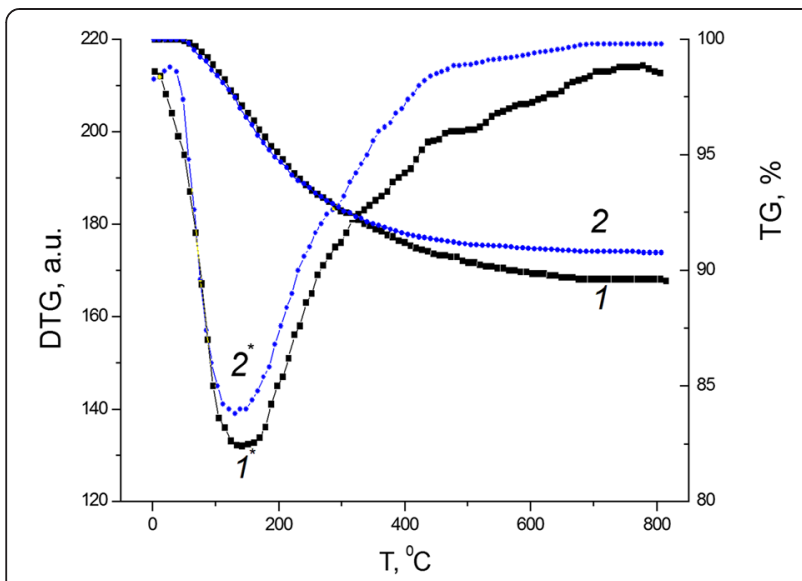

Fig. 2 TG and DTG-curves of natural clinoptilolite $\left(1,1^{*}\right)$ and clinoptilolite heated at $500^{\circ} \mathrm{C}\left(2,2^{*}\right)$

water loss at $900{ }^{\circ} \mathrm{C}$ for Transcarpathian clinoptilolite heated at different temperatures (Table 1). For instance, the samples thermally activated at $200-250{ }^{\circ} \mathrm{C}$ were characterized with a minimum of water loss $(6.1 \%)$. Relatively high amounts of water loss (9.4-9.8\%) were received for the clinoptilolite previously calcined at the temperature range of $300-500{ }^{\circ} \mathrm{C}$. In this case, the reverse dependence between water loss amounts and temperature of thermal treatment was received. Nevertheless, previous heating of the sample at $700{ }^{\circ} \mathrm{C}$ again caused a sharp decrease in clinoptilolite water loss.

Consequently, it could be proposed that, the temperature of the zeolite thermal pretreatment influences on a rate of adsorption equilibrium rather than on its sorption capacity of water at $200-250^{\circ} \mathrm{C}$. This suggestion could be confirmed by the fact that weight losses were $9.9 \%$ for the sorbent previously heated at 200 and $250{ }^{\circ} \mathrm{C}$ and then kept for $72 \mathrm{~h}$ in air with relative humidity of $70 \%$.

These effects appeared from decelerated process of rehydration, since changes of clinoptilolite porous structure were still reversible at $200-250{ }^{\circ} \mathrm{C}$. On the contrast, an irreversible deep amorphization of Transcarpathian clinoptilolite occured at $700{ }^{\circ} \mathrm{C}$ [33]. In general, DTGcurve is a differential curve of the sample weight change and describes the dependence of the weight loss rate from the temperature. For the studied clinoptilolite samples, DTG-curves were asymmetrical and some characteristic points were identified (Fig. 3). A broad DTG-maximum observed at low temperatures indicates the intensive thermal desorption of water. It should be noted that maximum rates of water loss were observed for all studied samples in the temperature range from 110 to $130(140){ }^{\circ} \mathrm{C}$, independently from previous thermal treatment conditions. Furthermore, this dissymmetry of the DTG-maximum could be caused by overlapping between a few quasielementary maximums, which suggests at least two types of molecular water physically bonded to the clinoptilolite surface. In this temperature range, the water loss did not significantly varied with the temperature of the sorbent preparation (6.3-7.0\%), except for the sample calcinated at $700{ }^{\circ} \mathrm{C}(4.4 \%)$. An isokinetic region (indicated by arrows on Fig. 3) was observed on DTG-curves at the temperature of $440-560^{\circ} \mathrm{C}$ for all samples, apart from the sorbent previously heated at $700{ }^{\circ} \mathrm{C}$.

Moreover, an undefined DTG-maximum was found for the clinoptilolite previously calcined at $250{ }^{\circ} \mathrm{C}$. It is known that a deep dehydroxylation of silica occurs in this

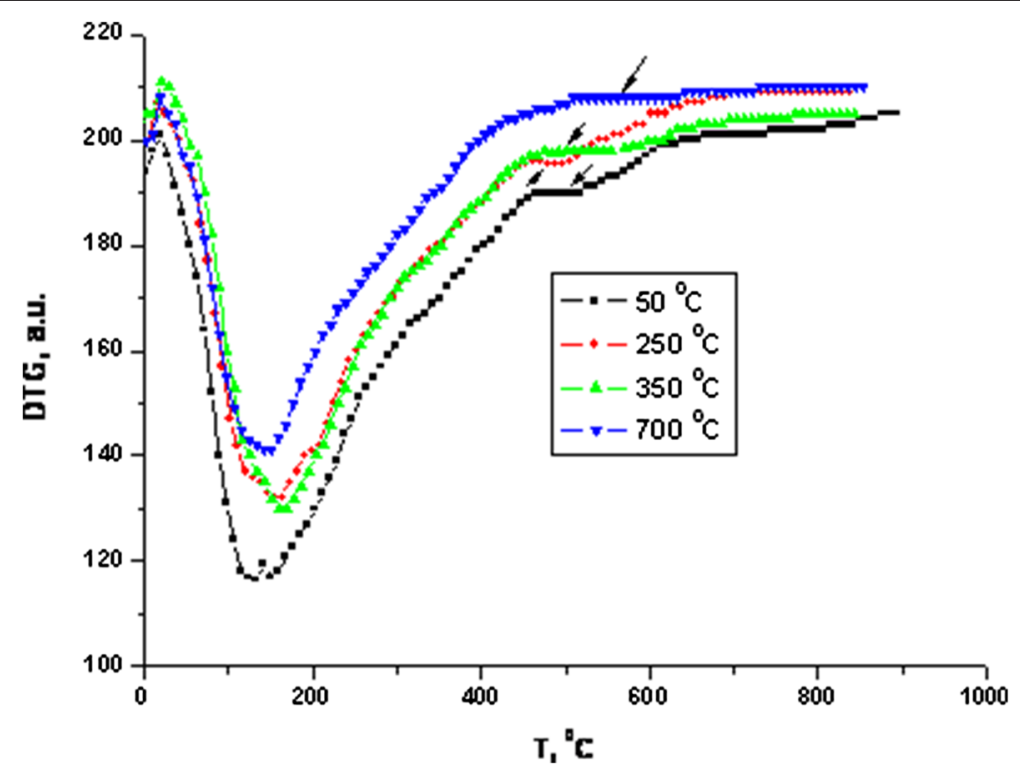

Fig. 3 DTG-curves of Transcarpathian clinoptilolite previously heated at different temperatures 
Table 1 Overall water loss at $900{ }^{\circ} \mathrm{C}$ for clinoptilolite samples previously heated at different temperatures

\begin{tabular}{lc}
\hline Temperature of the thermal pretreatment, ${ }^{\circ} \mathrm{C}$ & Water loss, $\%$ \\
\hline Unheated form & 10.4 \\
50 & 10.4 \\
100 & 10.0 \\
200 & 6.1 \\
$200^{\text {a }}$ & 9.9 \\
250 & 6.1 \\
$250^{\text {a }}$ & 9.9 \\
300 & 9.8 \\
350 & 9.7 \\
500 & 9.4 \\
700 & 6.6 \\
\hline${ }^{2}$ Clinoptilolite samples heated at the same conditions but additionally kept for \\
$72 \mathrm{~h}$ in air with relative humidity of $70 \%$
\end{tabular}

$72 \mathrm{~h}$ in air with relative humidity of $70 \%$

temperature range [38], and practically all $\mathrm{OH}$-groups appear to be isolated at temperature over $400{ }^{\circ} \mathrm{C}$. Consequently, the fully dehydroxylated surface is covered with oxygen atoms because of recombination of two hydroxyl groups and release of water molecules. This process demands reorganization of the surface atoms and also should be activated. Since surface dehydroxylation of the Transcarpathian clinoptilolite considerably diminishes the amount of surface $\mathrm{OH}$-groups responsible for the sorption of trace elements ions, the terbium sorption effectiveness of clinoptilolite heated above $400{ }^{\circ} \mathrm{C}$ was significantly decreased (Fig. 1).

It has been reported [39] that water molecules in the hydrated zeolite could form the cyclic hexamers with oxygen atoms of the sorbent framework. Due to these hydrogen bonds, water molecules did not contain free $\mathrm{OH}$-groups. Moreover, such cyclic hexamers prevent sorption of large cationic aqua and hydroxo complexes of metal ions. Desorption of ligand water molecules caused a simultaneous destruction of hydrogen bonds and cyclic hexamers at the temperature above $200{ }^{\circ} \mathrm{C}$. As a result, a number of free $\mathrm{OH}$-groups considerably increased due to water molecules of the broken hexamer, which were still bonded to the zeolite framework. Since the surface $\mathrm{OH}$-groups are mainly active sorption centers towards trace elements ions, a noticeable improvement of sorption properties of the clinoptilolite heated in the temperature range of 250-350 ${ }^{\circ} \mathrm{C}$ towards terbium ions (Fig. 1) was connected with the increased number of surface hydroxyl groups provided by water molecules and surface silanol $(\mathrm{Si}-\mathrm{OH})$ groups.

Permissible multiple contents $\left(\mathrm{C}_{\mathrm{ion}} / \mathrm{C}_{\mathrm{Tb}(\mathrm{III})}\right)$ of ions common in waters and wastewaters, that do not change the maximum sorption capacity of clinoptilolite towards
Table 2 Tolerance limits of some ions for terbium(III) sorption from aqueous solution of Transcarpathian clinoptilolite (concentration of $\mathrm{Tb}(\mathrm{III})-1 \mu \mathrm{g} \cdot \mathrm{mL}^{-1} ; \mathrm{pH} 8.25$ )

\begin{tabular}{ll}
\hline Species & Tolerance limit $\left(\mathrm{C}_{\text {ion }} / \mathrm{C}_{\mathrm{Tb}(\mathrm{III})}\right)$ \\
\hline $\mathrm{NH}_{4}^{+}, \mathrm{NO}_{3}^{-}$ & 2000 \\
$\mathrm{Na}^{+}, \mathrm{K}^{+}$ & 1500 \\
$\mathrm{Zn}^{2+}, \mathrm{Ca}^{2+}$ & 50 \\
$\mathrm{Cl}^{-}$ & 2500 \\
$\mathrm{Mg}^{2+}$ & 300 \\
$\mathrm{SO}_{4}^{2-}$ & 1000 \\
\hline
\end{tabular}

terbium ions, are led in Table 2. Increasing of the admixture concentration beyond a define value leads to the reduction in sorption effectiveness of the zeolite.

A $7 \mathrm{M}$ solution of $\mathrm{HNO}_{3}$ and a $1 \mathrm{M}$ solution of $\mathrm{NaCl}$ acidified with a hydrochloric acid to $\mathrm{pH} 2.5$ were preferred as desorbents for terbium(III) ions, because each of them provided almost full recovery of lanthanide (Table 3). As a result, the developed solid phase extraction procedure could be applied for the spectrophotometric determination of trace amounts of terbiu$\mathrm{m}(\mathrm{III})$ ions in aqueous samples.

\section{Sample preconcentration procedure}

The sorbent was grounded in a ball mill to $0.20-0.31 \mathrm{~mm}$ size and washed with distilled water. After drying at room temperature, the clinoptilolite sample was heated in the oven at $350{ }^{\circ} \mathrm{C}$ for $2.5 \mathrm{~h}$ and then stored in a desiccator. 0.5-2 L water sample was acidified with nitric acid to a $\mathrm{pH}$ value approximately 1 and heated on a sand bath for $1 \mathrm{~h}$. After the filtration through the dense paper filter, the $\mathrm{pH}$ of the water was adjusted to 7 with a sodium hydroxide solution, and then a borate buffer was added to maintain $\mathrm{pH}$ 8.25. The final concentration of a borate buffer in the sample solution was $2.5 \cdot 10^{-4} \mathrm{M}$. The obtained solution passed through SPE cartridge filled with $0.6 \mathrm{~g}$ of the prepared sorbent at a flow rate of $3 \mathrm{~mL} \cdot \mathrm{min}^{-1}$. After the loading of the sample, the cartridge was washed with $50 \mathrm{~mL}$ of double-distilled water at the same flow rate.

Table 3 Desorption effectiveness of terbium(III) ions from clinoptilolite $^{a}$

\begin{tabular}{ll}
\hline Eluent & Desorption (\%) \\
\hline $1 \mathrm{M} \mathrm{NaCl}$ & 75 \\
$1 \mathrm{M} \mathrm{NaCl}$ (adjusted to $\mathrm{pH} 2.5$ with HCl) & $95-100$ \\
$2.8 \mathrm{M} \mathrm{HNO}_{3}$ & 80 \\
$7 \mathrm{M} \mathrm{HNO}_{3}$ & 100 \\
$3.6 \mathrm{M} \mathrm{H}_{2} \mathrm{SO}_{4}$ & 30 \\
$2.4 \mathrm{M} \mathrm{HCl}$ & 60 \\
$6 \mathrm{M} \mathrm{HCl}$ & 70 \\
\hline
\end{tabular}

${ }^{\mathrm{a}}$ Flow rate of eluent through adsorption system $=1 \mathrm{~mL} \cdot \mathrm{min}^{-1}$; volume of the eluent employed $=15 \mathrm{~mL}$ 
Table 4 Determination of terbium(III) ions in the synthetic water sample with the composition similar to natural surface waters after ions preconcentration with clinoptilolite $(n=3, P=0.95)$

\begin{tabular}{|c|c|c|c|c|c|c|}
\hline \multirow{2}{*}{$\begin{array}{l}\text { Composition of synthetic } \\
\text { solution, } \mathrm{mg} \cdot \mathrm{L}^{-1}\end{array}$} & \multirow{2}{*}{$\begin{array}{l}\text { Volume of synthetic } \\
\text { solution, } \mathrm{mL}\end{array}$} & \multirow[b]{2}{*}{ Enrichment factor ${ }^{a}$} & \multicolumn{2}{|c|}{ Concentration of $\mathrm{Tb}(\mathrm{III}), \mathrm{ng} \cdot \mathrm{mL}^{-1}$} & \multirow[b]{2}{*}{ Recovery, \% } & \multirow[b]{2}{*}{ RSD, \% } \\
\hline & & & Added & Found & & \\
\hline$\overline{\mathrm{Na}^{+}(20), \mathrm{K}^{+}(5),}$ & 600 & 40 & 100 & $97 \pm 3.9$ & 97 & 1.6 \\
\hline $\mathrm{Mg}^{2+}(1), \mathrm{Ca}^{2+}(10)$, & 600 & 40 & 50 & $51 \pm 2.6$ & 102 & 2.08 \\
\hline $\mathrm{Fe}^{3+}(0.5), \mathrm{SO}_{4}^{2-}(5)$ & 1050 & 70 & 10 & $9,8 \pm 0.98$ & 98 & 4.02 \\
\hline $\mathrm{Cl}^{-}(20), \mathrm{HCO}_{3}^{-}(50)$ & 1950 & 130 & 5 & $4,7 \pm 0.53$ & 94 & 4.51 \\
\hline \multirow[t]{2}{*}{$\mathrm{NH}_{4}^{+}(1), \mathrm{Zn}^{2+}(0.005), \mathrm{NO}_{3}^{-}(1)$} & 1950 & 130 & 3 & $2,8 \pm 0.49$ & 93.3 & 7.1 \\
\hline & 1950 & 130 & 0 & N.D. ${ }^{b}$ & & \\
\hline
\end{tabular}

${ }^{\mathrm{a}}$ Enrichment factor $=$ volume of sample/volume of eluent

${ }^{\mathrm{b}}$ N.D. < Detection limit

Whereas, terbium(III) ions were desorbed with $15 \mathrm{~mL}$ of a $1 \mathrm{M}$ sodium chloride solution acidified with a hydrochloric acid to $\mathrm{pH} 2.5$ at a flow rate $1 \mathrm{~mL} \cdot \mathrm{min}^{-1} .5 \mathrm{~mL}$ of doubledistilled water was added to the eluate, and the $\mathrm{pH}$ was adjusted to 1 with hydrochloric acid. The obtained solution was made up to $25 \mathrm{~mL}$ volume with double-distilled water and thoroughly mixed. Terbium(III) content in the solution was determined spectrophotometrically with arsenazo III as an indicator. This procedure is described in detail in the experimental part. Overall, the proposed method for determination of $\mathrm{Tb}(\mathrm{III})$ ions had a linearity range from 2.5 to $200 \mathrm{ng} \cdot \mathrm{mL}^{-1}$. The detection limit was found to be $0.75 \mathrm{ng} \cdot \mathrm{mL}^{-1}$, and this parameter was calculated using the following equation:

$$
D L=3 S b / m
$$

where $S b$ is a standard deviation of blank and $m$ is a slope of the calibration curve. The sample preparation method was tested on a model solution with the composition similar to natural water. As can be seen from Table 4, the components of waters do not have considerable influence on the determination of trace amounts of terbium(III) ions. The analyte recoveries from spiked tap water were above $93 \%$.

\section{Conclusions}

A solid-phase extraction procedure was developed for spectrophotometric determination of trace amounts of terbium(III) ions in aqueous solution. Transcarpathian clinoptilolite heated at $350{ }^{\circ} \mathrm{C}$ for $2.5 \mathrm{~h}$ was applied as a SPE sorbent. Maximum sorption ability towards terbium(III) ions was observed after thermal activation of the clinoptilolite. The results of thermogravimetric investigations indicated a relationship between changes of zeolite structure during dehydration processes and its sorption abilities. It was shown that previous thermal treatment of clinoptilolite has an influence on its sorption capacity and the overall water loss, which suggests only partial reversibility of zeolite rehydration. Due to this fact, thermally activated samples of clinoptilolite maintain their sorption abilities towards trace elements ions, especially terbium(III) ions, in aqueous solutions.

The same sorption values were obtained for terbiu$\mathrm{m}$ (III) solutions with $\mathrm{pH} 8.25$ regulated with either a borate buffer or sodium hydroxide. A buffer solution maintains a $\mathrm{pH}$ value, which permits to improve metrological characteristics of the measurements. Moreover, in this case the constant ionic strenght minimizes influence of other water components on the sorption process of $\mathrm{Tb}(\mathrm{III})$ ions. The developed method offers a possibility to concentrate trace amounts of terbium(III) ions in the presence of water components. Permissible multiple contents of competing ions for terbium(III) ions sorption were the following: $2500\left(\mathrm{Cl}^{-}\right), 2000\left(\mathrm{NH}_{4}^{+}, \mathrm{NO}_{3}^{-}\right), 1500$ $\left(\mathrm{Na}^{+}, \mathrm{K}^{+}\right), 1000\left(\mathrm{SO}_{4}^{2-}\right), 300\left(\mathrm{Mg}^{2+}\right), 50\left(\mathrm{Ca}^{2+}, \mathrm{Zn}^{2+}\right)$. A 1.0 $\mathrm{M}$ sodium chloride solution acidified with hydrochloric acid to $\mathrm{pH} 2.5$ was used for quantitative desorption of terbium(III) ions., An enrichment factor of 130 was obtained under the optimum conditions. A wide range of linearity $\left(2.5-200 \mathrm{ng} \cdot \mathrm{mL}^{-1}\right)$ with detection limit of $0.75 \mathrm{ng} \cdot \mathrm{mL}^{-1}$ was achieved. The developed procedure was applied for the determination of terbium(III) ions in technological solutions, where recoveries and RSD values were $93.3-103.0 \%$ and $1.6-7.1$, respectively.

\section{Competing interests}

The authors declare that they have no competing interests.

\section{Authors' contributions}

VOV conceived of the ideas of the project, carried out SPE investigation and coordinated the project. VPZ was responsible for the thermogravimetric analysis, AVP performed X-ray fluorescence determination of terbium. OV defined the influence of borax solution on the effectiveness of the SPE extraction, and GVG determined the optimum SPE conditions fo terbium concentration. All authors contributed to the preparation of the manuscript, read and approved the final version.

\section{Acknowledgement}

This work was partially funded by the Ministry of Education and Science of Ukraine.

\section{Author details}

${ }^{1}$ Faculty of Chemistry, Ivan Franko National University of Lviv, 6 Kyryla and Mefodiya St., 79005 Lviv, Ukraine. ${ }^{2}$ Department of Chemistry and Physics, Lviv 
Academy of Commerce, 9 Samchuka St., 79011 Lviv, Ukraine. ${ }^{3}$ Department of Environmental Safety and Nature Protection, Lviv Polytechnic National University, 12 Bandera St., 79013 Lviv, Ukraine.

Received: 5 January 2015 Accepted: 10 July 2015

Published online: 27 August 2015

\section{References}

1. Emsley J. The elements 3-rd edition. Oxford: Clarendon Press; 1998.

2. Meshkova SB, Topilova ZM, Gerasimenko Gl. Polymetyl-methacrylate as a sorbent for effective recovery of lanthanides from solutions and highly sensitive luminescence determination of europium and terbium in waters. Zh Anal Khim. 1993;48(1):65-72.

3. Tatar E, Mihucz VG, Virag I, Racz L, Zaray G. Effect of four bentonite samples on the rare earth element concentrations of selected Hungarian wine samples. Microchem J. 2007;85:132-5.

4. Gschneidner KAJ, Eyring LR. Handbook on the Physics and Chemistry of Rare Earths. Moscow: Metallurgiya; 1982.

5. MacCarthy P, Klusman RW, Cowling SW, Rice JA. Water Analysis. Anal Chem. 1995;67:525-82.

6. Faghihian $\mathrm{H}$, Kabiri-Tadi M. A novel solid-phase extraction method for separation and preconcentration of zirconium. Microchim Acta. 2010;168:147-52.

7. Kagaya S, Maeba E, Inoue Y, Kamichatani W, Kajiwara T, Yanai H, et al. A solid phase extraction using a chelate resin immobilizing carboxymethylated pentaethylenehexamine for separation and preconcentration of trace elements in water samples. Talanta. 2009;79:146-52.

8. Yu JC, Jiang ZT, Liu HY, Yu J, Zhang L. $\beta$-Cyclodextrin epichlorohydrin copolymer as a solid-phase extraction adsorbent for aromatic compounds in water samples. Anal Chim Acta. 2003;477:93-101.

9. Ayata S, Kaynak I, Merdivan M. Solid phase extractive preconcentration of silver from aqueons samples. Environ Monit Assess. 2009;153:333-8.

10. Faghihian H, Hajishabani A, Dadfarnia S, Zamani H. Use of clinoptilolite loaded with 1-(2-pyridylazo)-2-naphthol as a sorbent for preconcentration of $\mathrm{Pb}(\mathrm{II})$, $\mathrm{Ni}(\mathrm{II}), \mathrm{Cd}(\mathrm{II})$ and $\mathrm{Cu}(\mathrm{II})$ prior to their determination by flame atomic absorption spectroscopy. Intern J Environ Anal Chem. 2009;89(4):223-31.

11. Thabano JRE, Breadmore MC, Hutchinson JP, Johns C, Haddad PR. Silica nanoparticle-templated methacrylic acid monoliths for in-line solid-phase extraction-capillary electrophoresis of basic analytes. J Chromatogr A. 2009:1216:4933-40.

12. Zougagh M, Pavon JMC, de Torres AG. Chelating sorbents based on silica gel and their application in atomic spectrometry. Anal Bioanal Chem. 2005;381:1103-13.

13. Yusof AM, Rahman MM, Wood AKH. Adsorption of some toxic elements from water samples on modified activated carbon, and red soil using neutron activation analysis. J Radioanal Nucl Chem. 2007;271:191-7.

14. Daorattanachai $P$, Unob F, Imyim A. Multi-element preconcentration of heavy metal 311 ions from aqueous solution by APDC impregnated activated carbon. Talanta. 2005;67:59-64.

15. Trohimenko A, Zaporozhets O. Stepwise extraction of coexistent iodine forms by the 314 polyurethane foam in water solutions. Visnyk Lviv Univ Ser Khim. 2012;53:185-91.

16. Dyachuk OA, Gubina TI, Melnikov GV. Adsorption preconcentration in the 316 luminescence determination of polycyclic aromatic hydrocarbons. Zh Anal Khim. 2009;64(1):7-11.

17. Tuzen M, Palar K, Soylak M. Enrichment/separation of cadmium (II) and lead (II) in environmental samples by solid phase extraction. J Hazard Mater. 2005;121:79-87.

18. Leboda R, Gierak A, Grochowicz P. On the application of carbosilicon adsorbents to analysis of organic pollutants. Ochr Środow. 1987;2-3(32-33):61-4.

19. DePena YP, López W, Burguera JL, Burguera M, Gallignani M, Brunetto R, et al. Synthetic Zeolites as sorbent material for on-line preconcentration of copper traces and its determination using flame atomic absorption spectrometry. Anal Chim Acta. 2000;403:249-58.

20. Budnyak TM, Yanovska ES, Tertykh VA, Voznyuk VI. Adsorption properties of composite sokirnitskiy clinoptilolite-polyaniline to anions of elements of the V-and VI- groups of the Periodic system of D.I. Mendeleev. Rep Natl Acad Sci Ukr. 2011;3:141-5.

21. Al-Degs YS, El-Sheikh AH, Al-Ghouti MA, Hemmateenejad B, Walker GM. Solid-phase extraction and simultaneous determination of trace amounts of sulphonated and azo sulphonated dyes using microemulsion-modifiedzeolite and multivariate calibration. Talanta. 2008;75:904-15.
22. Chen X, Chen S, Lui J, Wang J. Isolation of hemoglobin from human blood using solid phase extraction with lanthanum (III) modified zeolite. Microchim Acta. 2009;165:217-22.

23. Vasylechko VO, Lebedynets LO, Gryshchouk GV, Kuz'ma YuB, Vasylechko LO, Zakordonskiy VP, (2001) in Book of Proceedings - Stud. Surf. Sci. Catal., V.135 "Zeolites and Mesoporous Materials at the Dawn of the 21ST Century", Eds. Galarneau A, Renzo FDi, Fajula F, Vedrine J, Elsevier, Amsterdam, 8 p. (CD Version).

24. Vasylechko V, Gryshchouk G, Neroda I. Adsorption of Pb(II) on Transcarpathian clinoptilolite. Visnyk Lviv Univ Ser Khim. 2009;50:177-87.

25. Vasylechko VO, Lebedynets LO, Gryshchouk GV, Leboda R, SkubiszewskaZięba J. On the utility of Transcarpathian clinoptylolite in the adsorption of chloroform from aqueous solutions. Ochr Środow. 1998;3(70):27-30.

26. Vasylechko V, Gryshchouk G, Svidrak G, Korkuna O. Concentration of Sr(II) on transcarpathian clinoptilolite. Visnyk Lviv Univ Ser Khim. 2012;53:174-84.

27. Vasylechko V, Gryshchouk G, Mel'nyk A, Kalychak Y. Pre-concentration and determination of cerium using Transcarpathian clinoptilolite. Nauk Zapysky NaUKMA Khim Nauky Technol. 2011;118:10-6.

28. Vasylechko VO, Lebedynets LO, Gryshchouk GV, Leboda R, Skubiszewska-Zięba J. Investigations of usefulness of Transcarpathian zeolites in trace analysis of waters. Application of mordenite for the preconcentration of trace amounts of copper and cadmium. Chem Anal (Warsaw). 1999:44:1013-24.

29. Vasylechko V, Gryshchouk G, Suhnatsky M. Sorption of Zn(II) on Transcarpathian clinoptilolite. Visnyk Lviv Univ Ser Khim. 2011;52:148-58.

30. Vasylechko VO, Gryshchouk GV, Zakordonskiy VP, Patsay IO, Len' NV, Vyviurska OA. Sorption of terbium on Transcarpathian clinoptilolite. Microporous Mesoporous Mater. 2013;167:155-61.

31. Vasylechko VO, Gryshchouk GV, Lebedynets LO, Kuz'ma YB, Vasylechko LO, Zakordonskiy VP. Adsorption of Copper on Transcarpathian clinoptilolite. Adsorpt Sci Technol. 1999;17(2):125-34.

32. Tarasevich YI, Polyakov VE, Penchev VZ, Kirov GN, Minchev KI, Polyakov IG, et al. Ion-exchange qualities and structural features of clinoptilolites of various deposits. Khim Technol Vody. 1991;13(2):132-40.

33. Vasylechko VO, Gryshchouk GV, Kuz'ma YB, Zakordonskiy VP, Vasylechko LO, Lebedynets LO, et al. Adsorption of cadmium on acid-modified Transcarpathian clinoptilolite. Microporous Mesoporous Mater. 2003;60:183-96.

34. Vasylechko VO, Lebedynets LO, Gryshchouk GV, Kuz'ma YB, Vasylechko LO, Bernats'ka TM. Adsorption of Copper on Transcarpathian Mordenite. Adsorpt SciTechnol. 1996;14(5):267-77

35. Marczenko Z. Photometricheskoye opredeleniye elementov. Moscow: Mir; 1971.

36. Goryushina VG, Savvin SB, Romanova EV. Photometric determination of rare earths in ores with arsenazo III. Zh Anal Khim. 1963;18(11):1340-4.

37. Tsitsishvili GV, Andronikashvili TG, Kirov GN, Filizova LD. Prirodnye Tseolity. Moscow: Mir; 1985

38. Gregg SJ, Sigg KSW. Adsorpbtsia, udel'naya poverkhnost, poristost. Moscow: Mir; 1984.

39. Hunger J, Beta IA, Bohlig H, Lind C, Jobic H, Hunger B. Adsorption Structures of water in NaX Studied by DRIFT Spectroscopy and Neutron Powder Diffraction. J Phis Chem B. 2006;110:342-53.

$\begin{aligned} & \text { Publish with ChemistryCentral and every } \\ & \text { scientist can read your work free of charge } \\ & \text { "Open access provides opportunities to our } \\ & \text { colleagues in other parts of the globe, by allowing } \\ & \text { anyone to view the content free of charge." } \\ & \text { W. Jeffery Hurst, The Hershey Company. } \\ & \text { - available free of charge to the entire scientific community } \\ & \text { - peer reviewed and published immediately upon acceptance } \\ & \text { - cited in PubMed and archived on PubMed Central } \\ & \text { - yours - you keep the copyright } \\ & \text { Submit your manuscript here: } \\ & \text { htpp://www.chemistrycentral.com/manuscript/ }\end{aligned}$ Chemistry Central

